\title{
IMPLEMENTASI PENANAMAN NILAI KARAKTER JUJUR DAN DISIPLIN MELALUI EKSTRAKURIKULER WAJIB PENCAK SILAT TAPAK SUCI DI SMK MUHAMMADIYAH 2 BLORA
}

\author{
Wahyu Ginanjar, Grendi Hendrastomo dan Nur Endah Januarti \\ Universitas Negeri Yogyakarta \\ ginanjarwahyu470@gmail.com
}

\begin{abstract}
Abstrak
Penelitian ini bertujuan untuk mengetahui implementasi penanaman nilai karakter jujur dan disiplin beserta praktiknya saat di dalam maupun di luar melalui ekstrakurikuler wajib Tapak Suci di SMK Muhammadiyah 2 Blora. Metode penelitian yang digunakan adalah kualitatif. Hasil penelitian menunjukkan bahwa karakter jujur dan disiplin diterapkan menggunakan strategi pembinaan rohani, pemberian nasihat, pemberian hukuman, pembinaan mental dan metode pembiasaan dilengkapi dengan contoh pelatih yang diterapkan dalam latihan rutin dan Ujian Kenaikan Tingkat. Jujur dan displin dipraktikkan baik di dalam ekstrakurikuler Tapak Suci maupun diluar ekstrakurikuler Tapak Suci..

Kata Kunci : Tapak Suci, Nilai Karakter, Jujur, Disiplin
\end{abstract}

Abstract

This research is aimed to find out the implementation of building the values of trustworthiness and discipline character with the practice both implicit and explicit through Tapak Suci compulsory extracurricular in SMK Muhammadiyah 2 Blora. The method is qualitative. The result showed that the character values of trustworthiness and discipline could be applied by using spiritual guidance, counseling, giving penalties, mental developing, and using habitual method which provided examples of trainers applied in the regular training and grade examination. Trustworthiness and discipline could be applied in Tapak Suci inside and outside.

Keywords: Tapak Suci, Character Values, Trustworthiness, Disciplin

\section{Pendahuluan}

Kemerosotan moral dan karakter pada para generasi muda di Indonesia, dapat dilihat dari angka kenakalan remaja yang semakin lama semakin meningkat. Data dari Badan Pusat Statistik (BPS) (Utami, 2016:2) mengatakan bahwa pada tahun 2013 angka kenakalan remaja di Indonesia mencapai 6325 kasus, sedangkan pada tahun 2014 jumlahnya mencapai 7007 kasus dan pada tahun 2015 mencapai 7762 kasus. Adanya data tersebut artinya dari tahun 2013 - 2014 saja kenakalan remaja mengalami kenaikan sebesar $10,7 \%$ dan mengalami kenaikan lagi di tahun 2015. Selain kenakalan remaja, kasus kemerosotan moral atau karakter juga dapat dilihat melalui banyaknya kasus korupsi di Indonesia. Korupsi juga dilakukan oleh para pelajar yang mana salah satu bentuknya berupa perilaku menyontek yang ditunjukkan pada saat ulangan harian demi memperoleh hasil belajar berupa nilai tes yang tinggi atau setidak-tidaknya mencapai 
Adanya Kriteria Ketuntasan Minimal (KKM) (Rahmawati,dkk, 2015:2). Adanya permasalahan-permasalahan kenakalan remaja dan kasus korupsi seperti yang telah dijelaskan di atas, mengindikasikan perlu adanya penanaman serta perbaikan moral dan karakter manusia. Memperbaiki serta menanamkan moral dan karakter, tentu diperlukan upaya yang strategis. Salah satu upaya strategis yang dapat ditempuh yaitu melalui jalur pendidikan (Singh, 2019).

Pendidikan bisa berlangsung di keluarga, masyarakat, dan yang paling populer di sekolah. Pendidikan yang dimaksud di sini adalah pendidikan karakter, yang mana saat ini sudah semakin dikuatkan dengan munculnya Peraturan Presiden No 87 tentang Pengauatan Pendidikan Karakter. Merujuk pada Perpres tersebut, sekolah sebagai lembaga pendidikan formal memiliki banyak sekali upaya dalam menanamkan dan menguatkan karakter kepada para siswanya, salah satunya dengan cara mengintegrasikan pendidikan karakter dalam pengembangan diri melalui kegiatan ekstrakurikuler (Wibowo, 2013). Keunikan-keunikan dari ekstrakurikuler dapat mewadahi bakat dan potensi siswa yang pada akhirnya akan membentuk karakter masing-masing siswa di sekolah, seperti halnya yang ada di SMK Muhammadiyah 2 Blora.

SMK Muhammadiyah 2 Blora yang termasuk dalam lembaga pendidikan kejuruan, memiliki tujuan khusus yaitu menyiapkan siswa agar mampu memilih karir, ulet dan gigih dalam berkompetensi, beradaptasi di lingkungan kerja dan mengembangkan sikap profesional dalam bidang keahlian yang diminatinya (Direktorat Dikmenjur, 2003). Berdasarkan wawancara dengan Kepala SMK Muhammadiyah 2 Blora, untuk menerapkan tujuan khusus SMK tersebut bukanlah perkara yang mudah. Alasannya yaitu setiap siswa memiliki karakter yang berbeda-beda dan tidak sedikit dari mereka memiliki karakter yang negatif yang kemudian menjadi sedikit hambatan dalam penerapan tujuan membentuk tenaga profesional yang siap menghadapi dunia kerja. Lebih lanjut, juga dikatakan bahwa dengan banyaknya fenomena negatif tersebut menjadikan alasan pentingnya dilakukan perbaikan karakter siswa, yang dalam SMK Muhammadiyah 2 Blora sendiri dilakukan melalui ekstrakurikuler pencak silat khususnya Tapak Suci yang wajib diikuti oleh para siswa.

Pencak silat merupakan olahraga yang unik karena terdiri dari cabangcabang atau perguruan-perguruan pencak silat. Salah satu perguruan pencak silat yang terkenal yaitu Tapak Suci Putera Muhammadiyah atau biasa disingkat dengan sebutan Tapak Suci. SMK Muhammadiyah 2 Blora menjadikan Tapak Suci sebagai 
ekstrakurikuler wajib karena Tapak Suci memiliki peranan penting dalam penanaman dan penguatan mental atau karakter terutama karakter jujur dan disiplin. Hal ini dikuatkan oleh Anies Baswedan (H Yanuar, 2015) sebagai salah satu Pendekar Kehormatan Tapak Suci yang mengatakan bahwa Tapak Suci sebagai salah satu perguruan pencak silat bukanlah sekedar olahraga, tetapi justru menjadi ekspresi budaya dan karakter yang harus diajarkan kepada anak-anak Indonesia. Karakter yang dapat diajarkan yaitu kejujuran dan kedisiplinan, sehingga sekolah-sekolah harus memberikan tempat. Oleh karena itu, proses pendidikan yang di dalamnya terdapat pembinaan karakter jujur dan disiplin seharusnya tidak boleh diabaikan.

Jujur dan disiplin merupakan karakter yang sangat perlu untuk ditanamkan pada para pelajar sebagai generasi muda. Jujur dan disiplin perlu ditanamkan karena dapat melatih sikap mental dan keteguhan hati dalam melaksanakan apa yang seharusnya dilakukan dan telah diputuskan. Jika sudah tertanam karakter jujur dan disiplin pada jiwa para generasi muda, maka secara otomatis mereka akan membentengi dirinya dari sesuatu yang dapat menjerumuskan mereka kepada hal-hal yang negatif seperti kenakalan remaja, korupsi, dan penyimpangan sosial yang lainnya. Mereka akan bertindak selaras dengan nilai dan norma yang ada di masyarakat, sehingga nantinya akan membentuk kehidupan yang tentram dan harmonis. Bahkan, dapat mengarahkan Bangsa Indonesia ke arah kemajuan. Dengan memperhatikan hal-hal tersebut di atas, dalam penelitian memiliki tujuan untuk mengetahui implementasi penanaman nilai karakter jujur dan disiplin beserta praktiknya oleh siswa di dalam maupun di luar kegiatan ekstrakurikuler wajib pencak silat Tapak Suci di SMK Muhammmadiyah 2 Blora.

\section{Metode}

Penelitian ini dilakukan di SMK Muhammadiyah 2 Blora. Alasan peneliti mengambil lokasi penelitian di SMK Muhammadiyah 2 Blora adalah karena sekolah tersebut merupakan satusatunya sekolah yang mewajibkan siswanya terutama kelas $X$ untuk mengikuti ekstrakurikuler wajib Tapak Suci. Penelitian dilaksanakan selama 2 bulan mulai dari bulan November sampai Desember 2018.

Penelitian ini menggunakan metode penelitian kualitatif, yaitu suatu prosedur penulisan yang menghasilkan data-data deskriptif dalam suatu penelitian. Penelitian kualitatif adalah suatu penelitian yang ditunjukkan untuk mendeskripsikan dan menganalisis fenomena sosial serta pemikiran dari sudut pandang informan (Sukmadinata, 
2005:60). Menurut Fachan (Hamdi \& Bahruddin, 2014:11), terdapat tiga alasan diperlukannya penelitian kualitatif, yang mana salah satunya yang sesuai dengan penelitian ini yaitu metode penelitian kualitatif digunakan untuk mencapai dan memperoleh suatu cerita, pandangan yang segar dan sebagainya. Kemudian, metode penelitian kualitatif dapat memberikan suatu penjelasan secara terperinci tentang fenomena yang sulit disampaikan dengan metode kuantitatif, yang mana dalam penelitian ini berupa implementasi penanaman karakter jujur dan disiplin melalui Tapak Suci serta praktik karakter tersebut saat siswa berada di dalam maupun di luar ekstrakurikuler Tapak Suci.

Populasi penelitian dalam penelitian ini adalah warga SMK Muhammadiyah 2 Blora. Kemudian untuk pengambilan sampel digunakan teknik purposive sampling, yaitu teknik pengambilan sampel yang dilakukan dengan cara menetapkan kriteria untuk menjadikan seseorang sebagai informan penelitian demi mencapai tujuan dari sebuah penelitian (Djiwandono, 2015:78). Sedangkan yang menjadi sampel penelitian adalah warga SMK Muhammadiyah 2 Blora yang memiliki kriteria sebagai pengampu kebijakan yaitu kepala sekolah dan wakil kepala sekolah bidang kesiswaan, koordinator jalannya ekstrakurikuler wajib Tapak Suci, pelatih Tapak Suci dan pelaksana kegiatan ekstrakurikuler wajib Tapak Suci, yaitu siswa SMK Muhammadiyah 2 Blora yang terdiri dari kelas X, XI dan XII. Kemudian, sumber data yang digunakan dalam penelitian ini adalah sumber data primer dan sekunder. Sumber data primer diperoleh melalui observasi dan wawancara dengan kepala sekolah, wakil kepala sekolah bidang kesiswaan, koordinator atau pembina ekstrakurikuler wajib Tapak Suci dan siswa kelas X,XI, XII SMK Muhammadiyah 2 Blora. Sedangkan,sumber data sekunder dalam penelitian ini adalah mengenai peraturan tertulis wajibnya ekstrakurikuler Tapak Suci di SMK Muhammadiyah 2 Blora dan daftar hadir siswa yang ada di kegiatan Tapak Suci itu sendiri. Adapun teknik pengumpulan data dalam penelitian ini dilakukan dengan observasi, wawancara, dokumentasi dan kepustakaan.

Teknik analisis data yang digunakan dalam penelitian ini yaitu teknik analisis data Miles dan Huberman (Morissan, 2017:27) yang terdiri dari empat tahap mulai dari pengumpulan data, reduksi data, penyajian data dan penarikan kesimpulan.

\section{Hasil dan Pembahasan}

1. Ekstrakurikuler Wajib Pencak Silat Tapak Suci di SMK Muhammadiyah 2 Blora sebagai Pendidikan Karakter 
Karakter itu merupakan suatu nilai khas yang tertanam kuat dalam diri manusia dan dapat menggarahkan manusia tersebut dalam bertingkah laku. Karakter dapat dikuatkan melalui pendidikan karakter, yaitu suatu usaha untuk menanamkan nilai-nilai karakter pada manusia agar dapat bertingkah laku sesuai dengan kaidah kehidupan (Zulfah \& Shofa, 2019). Baik itu tingkah laku dengan Tuhan Yang Maha Esa, keluarga, diri sendiri dan masyarakat luas. Penguatan pendidikan karakter ini merupakan gerakan pendidikan untuk memperkuat karakter siswa melalui harmonisasi oleh hati, olah rasa, olah pikir dan olah raga dengan pelibatan kerjasama antara satuan pendidikan, keluarga dan masyarakat sebagai bagian dari Gerakan Nasional Revolusi Mental.

Salah satu upaya penanaman karakter melalui pendidikan karakter yang dilakukan di SMK Muhammadiyah 2 Blora yaitu melalui ekstrakurikuler Tapak Suci. Kedudukannya dalam kurikulum yaitu sebagai kegiatan pendidikan yang dilakukan oleh siswa di luar jam belajar kurikulum standar sebagai perluasan dari kegiatan kurikulum dan dilakukan di bawah bimbingan sekolah dengan tujuan untuk mengembangkan kepribadian, bakat, minat dan kemampuan siswa yang lebih luas atau di luar minat yang dikembangkan oleh kurikulum (Nuh, 2013:2). Artinya Tapak Suci sebagai ekstrakurikuler di SMK Muhammadiyah 2 Blora, sebagai pelengkap dan penunjang upaya pembinaan kepribadian, bakat dan minat siswa di luar kegiatan pembelajaran. Pembinaan kepribadian yang dimaksud yaitu bisa melalui penanaman karakter pada para siswa SMK Muhammadiyah 2 Blora.

Salah satu latar belakang
dijadikannya Tapak Suci sebagai
ekstrakurikuler wajib yaitu Tapak Suci dijadikan media dalam pendidikan karakter, yang mana digunakan untuk memperbaiki perilaku atau karakter para siswanya. Sebenarnya bukan hanya Tapak Suci, semua ekstrakurikuler di SMK Muhammadiyah juga mengandung berbagai nilai karakter yang dapat ditanamkan untuk membina karakter siswa. Akan tetapi, memang pada kenyataannya pendidikan karakter melalui ekstrakurikuler wajib terlihat lebih menonjol dibandingkan dengan ekstrakurikuler lainnya. Hal ini bisa terjadi karena tenaga pendidik dan kependidikan di SMK Muhammadiyah 2 Blora didominasi oleh kader-kader Tapak Suci. Adanya hal ini membuat Tapak Suci di SMK Muhammadiyah 2 Blora dalam pelaksanaannya lebih berjalan secara maksimal dibandingkan dengan ekstrakurikuler yang lain dan Tapak Suci selayaknya seperti dipilih sebagai media pendidikan karakter.

Ekstrakurikuler wajib Tapak Suci memiliki sejumlah materi yang wajib 
diberikan kepada siswa. Materi-materi tersebut berpedoman pada Anggaran Dasar dan Anggaran Rumah Tangga Tapak Suci dalam lingkup nasional. Materi-materi pendidikan Tapak Suci tersebut terdiri dari Al-Islam dan Kemuhammadiyahan (akidah, ibadah, akhlak, tarikh, Al-Qur'an dan Kemuhammadiyahan), ilmu pencak silat, pengetahuan organisasi, kesehatan olahraga dan kepelatihan. Materi-materi tersebut ditanamkan melalui metode pendidikan Tapak Suci yaitu ceramah, drill dan demonstrasi.

Berdasarkan metode-metode pendidikan Tapak Suci mulai dari ceramah, drill dan demonstrasi, ditanamkanlah karakter kepada siswa secara langsung dan tidak langsung. Secara langsung melalui metode ceramah, pemberian nasihat, hukuman, pembinaan mental dan pembiasaan dilengkapi dengan contoh pelatih.

Adapun teknis dalam pelaksanaan ekstrakurikuler Tapak Suci di SMK Muhammadiyah 2 Blora yaitu latihan Tapak Suci dilaksanakan tingkat per tingkat dan setiap tingkatan dilaksanakan dalam waktu 6 bulan. Kemudian, setiap latihan dipimpin oleh sekurangkurangnya 2 orang pelatih. Adapun rangkaian kegiatan latihan rutin ekstrakurikuler Tapak Suci yaitu do'a pembukaan, pembacaan ikrar, tausiyah atau pembinaan rohani oleh pelatih, penguluran dan pemanasan, penyampaian jurus atau materi tapak suci oleh pelatih, do'a penutupan dan berjabat tangan.Teknis latihan tersebut, mengandung falsafah pencak silat, yaitu falsafah budi pekerti luhur. Seperti yang dikatakan oleh Erwin Setyo Kriswanto (Kriswanto, 2015:17), bahwa falsafah pencak silat adalah falsafah budi pekerti luhur, yakni falsafah yang memandang budi pekerti luhur sebagai sumber dari keluhuran sikap, perilaku, dan perbuatan manusia yang diperlukan untuk mewujudkan cita-cita agama dan moral masyarakat.

Berkelanjutan dari pernyataan tersebut dikatakan oleh Awan Hariono (Hariono, 2008:550), bahwa falsafah dalam pencak silat merupakan tuntunan yang harus diterapkan baik dalam proses latihan maupun pertandingan. Artinya, selama proses latihan dan pertandingan harus mengutamakan pada prinsipprinsip dan nilai-nilai falsafah dalam pencak silat. Penerapan tersebut memiliki tujuan agar pesilat mampu memiliki karakter dan kepribadian yang positif sehingga menjadi manusia yang berguna bagi diri sendiri, agama, masyarakat dan bangsa. Selama proses latihan, pengembangan karakter pesilat diterapkan dari awal sampai akhir latihan.

Tapak Suci sebagai salah satu perguruan dalam pencak silat, memiliki berbagai nilai karakter yang terkandung dalam aspek-aspek pencak silat. Empat 
aspek pencak silat yang dikatakan oleh Awan Hariono (Hariono, 2008:549) yaitu, Aspek mental spiritual mengandung nilai : bertaqwa kepada Tuhan Yang Maha Esa, berbudi, tenggang rasa, percaya diri, disiplin, cinta bangsa dan tanah air, persaudaraan, pengendalian diri, tanggungjawab sosial dan solidaritas sosial. Kemudian aspek beladiri menuntut pesilat untuk wajib : 1) berani menegakkan kejujuran, kebenaran dan keadilan, 2) tahan uji dan tabah dalam menghadapi cobaan dan godaan, 3) tangguh atau ulet dan dapat mengembangkan kemampuan di dalam melakukan usaha, 4) tanggap, peka, cermat cepat dan tepat di dalam menelaah permasalahan yang dihadapi maupun dalam mengatasinya 5) selalu melaksanakan "ilmu padi", dan menjauhkan diri dari sikap dan perilaku sombong atau takabur dan 6) menggunakan keterampilan gerak efektifnya dalam perkelahian hanya karena keadaan terpaksa untuk keselamatan diri dan harga diri menurut ukuran obyektif serta keselamatan bangsa dan negara. Kemudian dalam aspek pengembangan seni, pesilat diharapkan memiliki keterampilan gerak yang serasi dan menarik, dilandasi dengan cinta terhadap budaya bangsa. Selanjutnya yang terakhir adalah aspek pengembangan olahraga, yang mana pesilat harus memiliki sifat taqwa, tanggap, tangguh, tanggon dan trengginas. Khusus dalam penelitian ini akan dibahas nilai karakter jujur dan disiplin sebagai karakter utama dalam pencak silat khususnya Tapak Suci.

\section{Implementasi Penanaman Nilai} Karakter Jujur dan Disiplin Melalui Ekstrakurikuler Wajib Tapak Suci di SMK Muhammadiyah 2 Blora

Tapak Suci sebagai salah satu organisasi otonom (ortom) dan amal usaha Muhammadiyah yang bergerak dalam bidang pendidikan, menjadi bagian dari sekolah-sekolah dalam bentuk ekstrakurikuler yang mana menjadi media pembentukan karakter siswa yang efektif.

Terdapat banyak karakter yang dapat diterapkan melalui Tapak Suci, dua di antaranya yang menjadi karakter utama yaitu jujur dan disiplin. Jujur merupakan kemampuan untuk berperilaku sebenar-benarnya dan berani mengakui kesalahan sehingga menjadikan dirinya sebagai manusia yang dapat dipercaya. Sedangkan disiplin merupakan kemampuan untuk menaati peraturan yang dibangun atas dasar kesadaran yang kuat dari diri manusia yang diwujudkan dalam sikap dan perilaku sehari-hari. Kejujuran sendiri dapat dilakukan dengan berperilaku tidak mencuri, tidak menyontek, mengakui kesalahan dan mampu mengatakan sesuatu sebenarbenarnya sesuai fakta yang ada. Sedangkan kedisiplinan dapat dilakukan 
dengan berperilaku menghargai waktu dan menaati peraturan yang telah dibuat.

Penanaman karakter jujur dan disiplin sehingga bisa menghasilkan siswa-siswa yang berprestasi tentunya tidak lepas dari berbagai subjek yang berperan di baliknya, yaitu kepala sekolah, bapak dan ibu guru, BK, koordinator ekstrakurikuler Tapak Suci, siswa dan pelatih Tapak Suci. Berdasarkan sekian banyak subjek yang berperan dalam penanaman karakter jujur dan disiplin tersebut, terdapat subjek utama yang paling berperan dalam penanaman karakter jujur dan disiplin, yaitu pelatih Tapak Suci. Hal ini dikarenakan pelatih merupakan subjek penanaman karakter yang turun langsung ke lapangan dalam menangani para siswa. Mereka memiliki berbagai ilmu yang dapat ditularkan kepada siswa dan memiliki berbagai upaya atau strategi dalam menangani berbagai karakter siswa di lapangan.

Tapak Suci melalui berbagai subjeknya dalam menanamkan karakter jujur dan disiplin menggunakan berbagai metode sebagai berikut :

a. Pembinaan rohani melalui tausiyah

Pemberian tausiyah diberikan kepada siswa pada saat sebelum dimulainya latihan dan kegiatankegiatan Tapak Suci lainnya dengan waktu minimal 1 jam. Pemberian tausiyah ini bertujuan untuk membina karakter dengan sasaran rohani para siswa. Selain itu melalu pembinaan rohani, siswa juga diajak untuk selalu ber amar ma'ruf nahi munkar, yaitu berlomba-lomba atau berseru dalam jalan kebaikan dan mencegah diri sendiri maupun orang lain dalam berbuat buruk atau dosa, yang mana dalam hal ini jujur dan disiplin termasuk ke dalam kebaikan dan sebaliknya ketidakjujuran dan ketidakdisiplinan termasuk dalam keburukan.

b. Pemberian Nasihat

Strategi pemberian nasihat ini merupakan strategi yang digunakan untuk menyampaikan pesan moral kepada hati dan diri siswa. Tujuannya untuk mencegah terjadinya perilaku negatif pada siswa. Penyampaian nasihat ini disampaikan dengan cara disisipkan pada sela-sela penyampaian tausiyah. Kemudian ketika siswa melakukan kesalahan, siswa tidak langsung dihukum tetapi diberikan nasihat. Pemberian nasihat juga tidak hanya dilakukan oleh satu pihak, yaitu dari pihak pelatih kepada siswa. Akan tetapi, siswa juga diperbolehkan atau bahkan berhak menasehati pelatih.

c. Pemberian Hukuman

Pembinaan dengan sistem hukuman atau sanksi ini merupakan strategi yang digunakan oleh pembina dan atau pelatih jika siswa sudah tidak bisa jika hanya diberikan nasihat. 
Kemudian juga jika siswa sudah terlalu sering melakukan kesalahan. Metode ini bertujuan agar siswa jera dan tidak mengulangi lagi kesalahannya. Sedangkan hukuman yang diberikan adalah hukuman yang sifatnya mendidik, misalnya push up, squad jump dan lain sebagainya, yang mana hukuman seperti itu bisa meningkatkan kualitas kekuatan fisik siswa.

d. Pembinaan Mental

Pembinaan mental dalam ekstrakurikuler Tapak Suci di SMK Muhammadiyah 2 Blora dilakukan dengan cara siswa dimasukkan ke dalam makam satu persatu untuk mencari sabuknya dan mendapatkan nasihat dari para siswa. Tujuan dari kegiatan ini adalah para siswa dilatih mentalnya untuk berani memasuki area pemakaman. Selain itu dengan melihat banyaknya makam, siswa juga diajak untuk mengingat bahwa di dunia itu manusia tidak selamanya hidup. Semua akan kembali ke akhirat, sehingga di dunia para siswa harus senantiasa berkelakuan dan melakukan hal-hal positif.

Mengenai metode pembinaan mental ini, setiap siswa tidak mendapatkan treatment yang sama. Khusus siswa yang memiliki catatan negatif saat di sekolah maupun di Tapak Suci disendirikan dari siswa yang lainnya. Siswa yang berkelakuan baik sebelum melakukan ujian mental menempuh rute perjalanan yang normal, yaitu berjalan kaki tanpa menggunakan alas kaki melewati jalan raya dan jalan perkampungan warga. Sesampainya di pemakaman siswa langsung melakukan ujian mental. Berbeda dengan siswa yang tidak memiliki catatan perilaku negatif, mereka yang dikategorikan sebagai siswa berperilaku negatif lebih dahulu melakukan ujian mental dan harus melewati rute yang lebih sulit. Para siswa melewati area persawahan, perkebunan jati dan sungai tanpa menggunakan alas kaki dan penerangan. Sesampainya di pemakaman siswa langsung diperintahkan melakukan ujian mental dan baru setelah itu mereka diajak berdiskusi dengan para penguji. Halhal yang didiskusikan berupa berbagai permasalahan yang sudah diperbuat oleh siswa. Mereka kemudian ditanya mengenai alasan mereka melakukan perilaku negatif dan penguji akan memberikan solusi. Saat proses diskusi ini, siswa harus bersikap terbuka atau terus terang agar ditemukan solusi yang tepat. Kemudian apabila terdapat siswa yang membantah akan diberikan hukuman hingga jera dan setelah itu siswa diajak berjanji untuk memperbaiki diri dan tidak lagi berperilaku negatif. Hal tersebut 
dilakukan dengan harapan supaya siswa bisa berkelakuan baik.

e. Strategi Pembiasaan Dilengkapi Contoh Langsung oleh Pelatih

Penanaman karakter jujur dan disiplin dalam Tapak Suci dapat diterapkan dengan strategi pemberian contoh langsung. Seperti yang dijelaskan oleh Empi Muslion bahwa pendidikan karakter tidak akan berhasil jika hanya diajarkan secara retorika dan ucapan-ucapan pendidik di depan kelas saja (Muslion, 2018:192). Berkaitan dengan hal tersebut artinya, pendidikan karakter yang dilakukan di Tapak Suci juga tidak bisa jika hanya disampaikan secara lisan atau melalui metode ceramah dan nasihat. Akan tetapi, harus terdapat figur nyata yang menjadi sosok keteladanan bagi siswa, yaitu para pelatih sebagai figur utama dalam penanaman karakter jujur dan disiplin. Para pelatih sebagai figur atau subjek utama penanaman karakter, berusaha membiasakan diri untuk selalu berperilaku positif terutama pada hal kejujuran dan kedisiplinan.

Para pelatih membiasakan dan mencontohkan kepada para siswa dengan perilaku-perilaku yang sederhana. Kedisiplinan dibiasakan dan dicontohkan dengan selalu menggunakan seragam yang lengkap dan datang tepat waktu. Sedangkan kejujuran dibiasakan dan dicontohkan dengan selalu berbicara apa adanya tanpa melebih-lebihkan dan tanpa berbohong kepada siapapun. Pemberian contoh langsung oleh pelatih ini tidak hanya ditunjukkan sebagai bentuk formalitas di dalam ekstrakurikuler Tapak Suci, tetapi juga di segala kondisi dan tempat di manapun mereka berada. Hal tersebut terjadi karena karakter positif khususnya jujur dan kedisiplinan sudah menjadi kebiasaan oleh para pelatih.

Pembiasaan dan pemberian contoh langsung yang dilakukan dalam ekstrakurikuler wajib Tapak Suci merupakan metode atau strategi yang efektif dalam menanamkan karakter jujur dan disiplin. Serupa dengan hal tersebut dikatakan oleh Fadillah dan Khorida (Hadisi, 2015:63) bahwa metode keteladan adalah metode yang dirasa paling meyakinkan keberhasilannya dalam mempersiapkan dan membentuk moral spiritual dan sosial anak. Metode keteladanan akan mempermudah anak didik dalam menerapkan ilmu yang dipelajari di sekolah, guru mudah dalam mengevaluasi hasil belajar, tujuan pendidikan lebih terarah dan tercapai dengan baik, akan tercipta suasana yang baik, hubungan yang harmonis antara guru dan siswa, serta 
mendorong guru untuk selalu berbuat baik karena akan dicontoh siswanya (Murdiastomo, 2017). Sedangkan pembiasaan, merupakan metode yang dipandang sangat praktis dalam pembinaan pembentukan karakter anak dalam mengingkatkan pembiasaan-pembiasaan dalam melaksanakan suatu kegiatan di sekolah. Kemudian di dalam sejarah juga tercatat sebagai metode yang berhasil dalam pembentukan kepribadian peserta didik (Rahmawati, 2011:27).

Pembiasaan yang dilakukan oleh para pelatih dengan senantiasa berperilaku jujur dan disiplin, kemudian diterapkan pada kehidupan sehari-hari dan dilihat oleh para siswa. Dengan seperti itu, karakter jujur dan disiplin menjadi efektif untuk ditiru dan diteladani oleh para siswa tanpa mengharuskan para pelatih untuk banyak berbicara mengenai kejujuran dan kedisiplinan. Artinya dengan seperti itu siswa bisa langsung melihat dan mendengar apa yang diperbuat oleh pelatih. Hal ini kemudian merangsang siswa untuk berperilaku jujur dan disiplin seperti para pelatih yang mereka teladani. Siswa yang sudah berperilaku baik, selanjutnya bisa menularkan dan menjadi contoh dari teman-temannya yang lain. Kemudian pada akhirnya karakter jujur dan disiplin bisa tertanam kuat pada seluruh anggota ekstrakurikuler Tapak Suci di SMK Muhammadiyah 2 Blora.

Berdasarkan metode-metode penanaman karakter jujur dan disiplin yang sudah dipaparkan di atas mulai dari pembinaan rohani, pemberian nasihat, pemberian hukuman, pembinaan mental dan metode pembiasaan dilengkapi dengan contoh pelatih, terdapat metode yang dominan dalam meningkatkan karakter jujur dan disiplin pada diri siswa yaitu metode pembiasaan dilengkapi dengan contoh pelatih. Alasannya yaitu dengan metode ini siswa bisa dengan mudah melihat secara langsung praktik kebiasaankebiasaan positif dari para senior atau pelatih khususnya dalam hal kejujuran dan kedisiplinannya. Setelah itu siswa bisa langsung meniru mempraktikkannya tanpa harus banyak melakukan pemahaman mengenai arti karakter jujur dan disiplin melalui kata-kata dan kalimatkalimat mengenai konsep karakter jujur dan disiplin. Sedangkan metode penanaman karakter jujur dan disiplin yang paling sering atau dominan dilakukan yaitu metode pembinaan rohani. Alasannya karena pada setiap kegiatan rutin, metodde ini sudah pasti masuk kedalam teknis kegiatan Tapak Suci dan tentu sudah pasti dilakukan. Metode pembinaan rohani 
ini dilakukan setiap latihan rutin dengan waktu kurang lebih selama 1 jam x 60 menit.

Praktik karakter khususnya jujur dan disiplin di dalam ekstrakurikuler wajib Tapak Suci dimunculkan dalam dua kegiatan yang kontinyu dan terprogram, yaitu latihan rutin dan Ujian Kenaikan Tingkat. Kegiatan pokok yang pertama dalam menanamkan karakter jujur dan disiplin pada siswa SMK Muhammadiyah 2 Blora melalui Tapak Suci yaitu latihan rutin. Kegiatan tersebut merupakan kegiatan pokok dalam ekstrakurikuler Tapak Suci. Latihan rutin ini dilaksanakan setiap hari Senin, Kamis dan Jum'at. Tujuan diadakannya kegiatan ini adalah untuk memberikan kemampuan dasar mengenai materimateri Ketapaksucian. Selain itu juga bertujuan untuk membina karakter siswa SMK Muhammadiyah 2 Blora. Sedangkan Ujian Kenaikan Tingkat atau yang disingkat UKT merupakan kegiatan evaluasi mengenai seberapa besar daya serap materi yang diberikan oleh pelatih selama kegiatan latihan rutin berlangsung. Kegiatan UKT ini terdiri dari berbagai tahap ujian. Mulai dari ujian tertulis, ujian ragawi, ujian mental dan ujian longmarch.

3. Praktik Karakter Jujur dan Disiplin di Dalam dan di Luar Kegiatan

\section{Ekstrakurikuler Wajib Tapak Suci} di SMK Muhammadiyah 2 Blora

Para pelatih yang notabene terjun langsung di lapangan, mengimplementasikan karakter jujur dan disiplin dalam dua kegiatan Tapak Suci di SMK Muhammadiyah 2 Blora, yaitu latihan rutin dan Ujian Kenaikan Tingkat. Ketika latihan rutin, siswa yang terlambat akan melakukan penghormatan kepada pelatih dan mengatakan alasan mereka terlambat. Pelatih sebelumnya tidak mengawali bertanya kepada para siswa yang terlambat. Akan tetapi membiarkan siswa mengutarakan keterlambatan mereka dengan sendirinya. Ketika siswa tidak mengutarakan keterlambatannya, baru kemudian pelatih bertanya kepada siswa. Selanjutnya ketika diperintahkan untuk melakukan sesuatu seperti sit up, push up dan lain sebagainya, pelatih tidak mengawasi siswa secara terusmenerus. Akan tetapi pelatih cukup melihat wajah para siswa yang berkeringat atau tidak. Secara tidak langsung hal-hal tersebut melatih siswa untuk terbiasa jujur dalam latihan rutin.

Sedangkan kedisiplinan dalam latihan rutin diterapkan dengan mencontohkan kepada siswa untuk mengerjakan sesuatu setepat mungkin. Misalnya ketika memasuki waktu sholat, pelatih mengajak para siswa untuk segera sholat dan mengimaminya. Kemudian ketika terdapat orang lain berbicara, siswa diperintahkan untuk 
diam. Selain itu pelatih juga mencontohkan untuk menggunakan seragam yang lengkap

Ketika Ujian Kenaikan Tingkat, siswa juga dibiasakan mengikuti semua kegiatan dengan tepat. Jika mereka tidak kuat dalam mengikuti rangkaian ujian mereka diminta untuk jujur terhadap pelatih dan akan diberikan solusi yang tepat. Siswa juga diminta mengerjakan ujian dengan mandiri dalam waktu yang telah ditentukan. Ketika siswa mulai bertindak tidak jujur, pelatih menegur perbuatan tersebut. Kemudian siswa juga berbaris dengan rapi serta memperhatikan orang lain yang berbicara. Pelatih dalam hal ini tidak segan mencontohkannya. Misalnya ketika pelatih memperhatikan pendekar yang sedang berbicara dan berusaha diam serta berbaris rapi ketika upacara. Hal-hal tersebut dapat melatih kejujuran dan kedisiplinan siswa saat Ujian Kenaikan Tingkat.

Cara-cara yang diterapkan dalam latihan rutin dan Ujian Kenaikan Tingkat tentunya diterima oleh para siswa dengan baik. Akan tetapi, meskipun diterima dengan baik cara-cara tersebut tidak menyebabkan siswa secara keseluruhan menjadi jujur dan disiplin. Masih terdapat beberapa siswa yang kurang jujur dan kurang disiplin. Akan tetapi, mereka sudah lebih baik daripada sebelumya.
Kegiatan latihan rutin dan Ujian Kenaikan Tingkat beserta berbagai strategi yang diterapkan oleh para pelatih seperti pembinaan rohani, pemberian nasihat, pemberian hukuman, pembinaan mental dan pembiasaan dilengkapi contoh langsung oleh pelatih, siswa dituntut dan didorong untuk berkelakuan baik termasuk jujur dan disiplin. Siswa dituntut untuk mematuhi segala aturan yang dibuat, menaati setiap intruksi pelatih, dibiasakan untuk berperilaku jujur dan disiplin, menghargai waktu dan lain sebagainya.

Seperti yang dikatakan oleh Ika Suci Wulandari dan Taufiq Hidayat (Wulandari \& Hidayat, 2014:600) bahwa terdapat konsekuensi yang menyenangkan dan tidak menyenangkan dalam mengubah tingkah laku. Konsekuensi menyenangkan berbentuk reward dan konsekuensi tidak menyenangkan berbentuk punishment. Dalam Tapak Suci, konsekuensi-konsekuensi tersebut juga berlaku. Reward akan di rasakan jika mampu berbuat jujur dan disiplin. Sedangkan punishment akan didapatkan jika siswa berbuat tidak jujur dan tidak disiplin.

Kemudian, berkat adanya dorongan dan tuntutan di dalam ekstrakurikuler wajib Tapak Suci, memberikan efek yang baik terkait dengan kejujuran dan kedisiplinan siswa. Berikut merupakan praktik karakter jujur 
siswa di dalam kegiatan ekstrakurikuler Tapak Suci :

a. Siswa menjawab pertanyaan pelatih dengan jujur pada saat latihan. Misalnya siswa ditanya tentang pemahaman materi yang sudah disampaikan. Ketika terdapat ketidakpahaman dengan materi yang disampaikan pelatih, siswa diminta untuk jujur dan menanyakan materi yang dibingungkan pada saat latihan itu juga.

b. Siswa jujur ketika diminta untuk melaksanakan latihan secara mandiri baik di dalam latihan maupun latihan mandiri di rumah.

c. Siswa mengakui keterlambatan saat datang latihan dengan mengungkapkan alasan yang jelas.

d. Siswa mengungkapkan alasan yang jelas ketika tidak bisa mengikuti ekstrakurikuler wajib Tapak Suci.

e. Menulis rapor hasil tes fisik dengan jujur. Misalnya ketika siswa diperiksa kemampuan fisiknya untuk melakukan push up, sit up, lari dan lain sebagainya, siswa benar-benar melakukan dan mencatatnya ke dalam rapor fisik sesuai dengan yang mereka lakukan.

f. Siswa mampu berkata jujur ketika tidak membawa kartu peserta latihan.

g. Berdasarkan hasil observasi, siswa jujur saat mengerjakan ujian atau tes tertulis pada Ujian Kenaikan Tingkat.
Kegiatan tersebut memiliki 4 sesi ujian, yang mana salah satunya adalah ujian tertulis. Sikap jujur yang terlihat dalam sesi ujian tertulis ini adalah siswa mengerjakan secara mandiri tanpa menyontek siswa yang lain.

h. Berdasarkan hasil observasi, siswa tidak berbohong ketika menjalani rangkaian ujian Kenaikan Tingkat. Ujian Kenaikan Tingkat mempunyai serangkaian sesi kegiatan yang sangat panjang dan diikuti oleh ribuan peserta tiap periodenya. Oleh karena itu, terkadang ketika siswa lupa melaksanakan ujian tertentu, Apabila terjadi hal seperti itu, pelatih atau tim penguji akan memanggil siswa yang bersangkutan dan menanyakan apakah siswa benarbenar sudah melaksanakan materi ujian atau belum. Kemudian apabila siswa menyadari bahwa ia belum melaksanakan salah satu materi ujian, ia menjawab dengan jujur dan siap melaksanakan ujian yang diberikan oleh tim penguji.

Karakter kedisiplinan tidak kalah pentingnya dengan kejujuran. Berikut merupakan praktik karakter disiplin siswa di dalam ekstrakurikuler Tapak Suci :

a. Datang lebih awal atau tepat waktu saat latihan atau ekstrakurikuler Tapak Suci.

b. Siswa disiplin memakai seragam dengan lengkap, yaitu memakai 
seragam atasan dan bawahan, sabuk dan khusus pada siswa puteri seragam atasan menutupi pantat dan memakai jilbab berwarna hitam.

c. Siswa melaksanakan setiap intruksi pelatih dengan sigap dan tanpa banyak protes.

d. Siswa disiplin terhadap dirinya sendiri dengan berusaha diam dan mendengarkan dengan seksama saat ada orang lain yang sedang berbicara. Hal ini dapat dilihat ketika para pelatih menyampaikan tausiyah dan materi. Seluruh siswa diperkenankan untuk diam dan memperhatikan pelatih dan boleh berbicara ketika ada kesempatan untuk bertanya.

e. Siswa disiplin mengantri dengan rapi saat pembagian tanda tingkat pada Ujian Kenaikan Tingkat meskipun dalam keadaan yang lelah.

f. Siswa disiplin berbaris dengan rapi pada saat upacara pembukaan maupun penutupan Ujian Kenaikan Tingkat.

Keberhasilan implementasi penanaman karakter jujur dan disiplin melalui ekstrakurikuler wajib Tapak Suci di SMK Muhammadiyah 2 Blora, pada akhirnya memberikan efek bagi kehidupan siswa di luar kegiatan ekstrakurikuler Tapak Suci. Muh Kolil M.Pd.i (Lestari M., 2018) mengatakan bahwa penanaman karakter disiplin yang ditanamkan di sekolah menjadikan pribadi yang lebih baik dalam lingkup sekolah maupun luar sekolah. Dengan disiplin tentu tingkat kedisiplinan melalui Tapak Suci makin baik. Begitu pula dengan tanggungjawab mereka. Dengan demikian jelaslah dalam penanaman karakter disiplin sangat berpengaruh dalam kehidupan sehari-hari. Sedangkan kejujuran, melalui perintah-perintah pelatih dan hukuman siswa perlahan sadar untuk berlaku jujur terhadap diri sendiri dan orang lain diawali dari lingkungan latihan atau sekolah menuju lingkungan keluarga dan masyarakat melalui pembiasaan sederhana (Wisnu, 2016:57).

Berdasarkan uraian di atas, artinya para siswa yang dibina melalui ekstrakurikuler wajib Tapak Suci pada akhirnya akan selalu berperilaku jujur dan disiplin. Mereka menyadari akan perilaku yang salah dan benar. Kesadaran untuk berperilaku baik terutama jujur dan disiplin kemudian pada akhirnya menjadi melekat kuat pada diri siswa. Perilaku jujur dan disiplin tersebut diterapkan dan dipraktikkan tidak hanya dalam kegiatan ekstrakurikuler Tapak Suci. Akan tetapi, juga diterapkan dan dipraktikkan di luar ekstrakurikuler Tapak Suci, seperti di kelas dan di rumah. Berikut merupakan praktik karakter jujur oleh siswa di luar kegiatan ekstrakurikuler wajib Tapak Suci : 
a. Siswa ketika mengerjakan ulangan selalu mengerjakan secara mandiri, tidak menyontek atau menanyakan kepada siswa yang lainnya.

b. Ketika ditanya oleh orangtua ataupun guru di sekolah, siswa sudah bisa menjelaskan dan menjawab pertanyaan sesuai dengan fakta yang ada tanpa dibuatbuat.

c. Ketika mengkonsumsi makanan ataupun minuman di kantin, siswa membayar sesuai dengan apa yang sudah mereka makan ataupun minum.

d. Saat dilaksanakan sidak atau operasi handphone di sekolah, siswa yang memiliki konten-konten negatif terlebih dahulu jujur merasa bersalah dan menyerahkan handphonenya kepada guru yang bersangkutan.

e. Ketika diberikan waktu istirahat untuk makan, minum dan menjalankan ibadah, siswa benarbenar jujur melaksanakan ibadah, tidak hanya makan dan minum saja.

f. Jujur saat tidak mengerjakan tugas yang diberikan oleh guru.

g. Ketika siswa diberi uang oleh orangtua untuk keperluan membayar iuran seperti SPP dan lain sebagainya, siswa tidak berbohong dan benar-benar membayarkannya pada pihak sekolah yang bersangkutan.
Sama halnya dengan kejujuran, karakter disiplin juga melekat dalam diri siswa. Karakter disiplin yang dijarakan melalui ekstrakurikuler wajib Tapak Suci diterapkan oleh siswa dalam kehidupan sehari-hari. Berikut merupakan karakter disiplin yang dipraktikkan oleh siswa di luar kegiatan ekstrakurikuler Tapak Suci:

a. Siswa berusaha rajin untuk berangkat ke sekolah dan datang lebih awal atau minimal tepat waktu.

b. Siswa mengaku lebih bisa mengatur waktu antara bermain dan belajar dan lain sebagainya, setelah dibina melalui Tapak Suci.

c. Siswa terbiasa memakai atribut sekolah secara lengkap setiap harinya sesuai dengan yang telah dijadwalkan.

d. Siswa melakukan ibadah secara tepat waktu.

e. Ketika diberikan perintah atau tugas oleh guru, siswa langsung mengerjakannya dan mengumpulkan pekerjaan tepat pada waktunya.

Keberhasilan penanaman karakter jujur dan disiplin melalui Tapak Suci selain karena adanya dorongan dari strategi-strategi penanaman karakter dan kegiatan Tapak Suci, juga dipengaruhi oleh adanya strategi khas dari Tapak Suci, yaitu pemberian hukuman dan pembinaan mental. Kedua strategi tersebut menggunakan paksaan yang banyak dilarang dalam penanaman 
karakter, sebaliknya justru dibutuhkan dalam menanamkan karakter jujur dan disiplin bagi para siswa SMK Muhammadiyah 2 Blora. Pemberian hukuman dan pembinaan mental memberikan efek jera dan membuat mereka menyadari kesalahannya. Pemberian hukuman dan pembinaan mental yang erat dengan cara paksaan, justru menjadi cara yang efektif bagi Tapak Suci dalam menanamkan karakter jujur dan disiplin bagi para siswa SMK Muhammadiyah 2 Blora.

\section{Simpulan}

Karakter merupakan suatu nilai khas yang tertanam kuat dalam diri manusia dan dapat mengarahkan manusia tersebut dalam bertingkah laku. Karakter dapat dibentuk dan dan dikuatkan melalui pendidikan karakter, yaitu suatu usaha untuk menanamkan nilai-nilai karakter pada manusia agar dapat bertingkah laku sesuai dengan kaidah kehidupan. Pendidikan karakter harus dilaksanakan oleh semua satuan pendidikan, termasuk SMK Muhammadiyah 2 Blora.

Upaya penanaman karakter di SMK Muhammadiyah 2 Blora dilaksanakan dengan berbagai program, salah satunya melalui ekstrakurikuler wajib pencak silat Tapak Suci. Ekstrakurikuler ini berjalan lancar dalam upaya penanaman karakter karena tenaga pendidik dan kependidikan SMK Muhammadiyah 2
Blora didominasi oleh kader-kader Tapak Suci. Adanya hal tersebut menjadikan ekstrakurikuler Tapak Suci selayaknya seperti dipilih menjadi media penanaman karakter. Adapun materi-materi pembinaan Tapak Suci dalam penanaman karakter meliputi Al-Islam dan Kemuhammadiyahan, ilmu pencak silat, pengetahuan organisasi, kesehatan olahraga dan kepelatihan. Materi-materi tersebut secara implisit mengandung unsur-unsur pembinaan karakter. Selain melalui materi-materi tersebut, pembinaan karakter juga dicerminkan melalui teknis latihan rutin ekstrakurikuler Tapak Suci mulai dari do'a pembukaan, pembacaan ikrar, tausiyah, penguluran dan pemanasan, penyampaian jurus atau materi ragawi Tapak Suci, do'a penutupan dan berjabat tangan. Teknis kegiatan Tapak Suci tersebut mengandung falsafah budi pekerti luhur pencak silat yang dijadikan sumber dari keluhuran sikap, perilaku dan perbuatan manusia.

Jujur merupakan kemampuan untuk berperilaku sebenar-benarnya dan berani mengakui kesalahan, sehingga menjadikan dirinya sebagai manusia yang dapat dipercaya. Sedangkan disiplin merupakan kemampuan untuk menaati peraturan yang dibangun atas dasar kesadaran yang kuat dari diri manusia yang diwujudkan dalam sikap dan perilaku sehari-hari. Subjek utama dalam upaya penanaman karakter jujur 
dan disiplin dalam Tapak Suci yaitu pelatih Tapak Suci karena terjun langsung di lapangan dalam menangani para siswa.

Berbagai macam karakter dimiliki para siswa SMK Muhammadiyah 2 Blora, baik itu positif maupun negatif. Karakter positif khususnya jujur dan disiplin ditanamkan oleh Tapak Suci melalui berbagai macam strategi, yaitu pembinaan rohani melalui tausiyah, pemberian nasihat, pemberian hukuman, pembinaan mental dan pembiasaan dilengkapi contoh langsung oleh pelatih. Strategi-strategi tersebut diterapkan dalam dua kegiatan Tapak Suci di SMK Muhammadiyah 2 Blora, yaitu latihan rutin dan Ujian Kenaikan Tingkat.

Karakter jujur dan disiplin banyak dipraktikkan oleh siswa baik di dalam maupun di luar ekstrakurikuler Tapak Suci. Praktik jujur dalam ekstrakurikuler Tapak Suci antara lain: menjawab pertanyaan pelatih dengan jujur, jujur ketika diminta melaksanakan latihan secara mandiri, mengakui keterlambatan, mengungkapkan alasan yang jelas ketika tidak menghadiri ekstrakurikuler Tapak Suci, jujur ketika tidak membawa kartu peserta latihan, menulis rapor tes fisik dengan jujur, mengerjakan tes tertulis dengan jujur dan tidak berbohong ketika menjalani rangkaian Ujian Kenaikan Tingkat. Sedangkan karakter disiplin yang dipraktikkan dalam ekstrakurikuler Tapak
Suci antara lain : datang lebih awal atau tepat waktu, memakai seragam lengkap, melaksanakan setiap intruksi pelatih dengan sigap, disiplin mengikuti setiap rangkaian kegiatan Tapak Suci, berusaha diam dan mendengarkan orang lain yang berbicara, mengantri dengan rapi saat pembagian tanda tingkat dan berbaris dengan rapi saat upacara pembukaan maupun penutupan Ujian Kenaikan Tingkat.

Karakter jujur dan disiplin juga dipraktikkan di luar kegiatan ekstrakurikuler Tapak Suci baik di rumah dan sekolah antara lain. Praktik karakter jujur di luar ekstrakurikuler Tapak Suci antara lain : mengerjakan ulangan dengan mandiri, menjelaskan dan menjawab pertanyaan guru maupun orangtua sesuai dengan fakta yang ada, membayar makanan dan minuman di kantin sesuai dengan yang dikonsumsi, siswa yang memiliki konten negatif mengaku bersalah sebelum operasi handphone dimulai, jujur saat beribadah, jujur ketika tidak mengerjakan tugas dan amanah jika diperintahkan membayar SPP atau keperluan di sekolah. Sedangkan karakter disiplin yang dipraktikkan di luar kegiatan Tapak Suci antara lain : rajin berangkat ke sekolah dan minimal datang dengan tepat waktu, bisa mengatur waktu belajar dan bermain, memakai seragam sekolah dengan atribut yang lengkap, melakukan ibadah dengan tepat waktu, 
mengerjakan serta mengumpulkan pekerjaan yang perintah oleh guru tepat pada waktunya.

Keberhasilan penanaman karakter jujur dan disiplin melalui Tapak Suci selain karena adanya dorongan dari strategi-strategi penanaman karakter dan kegiatan Tapak Suci, juga dipengaruhi oleh adanya strategi khas dari Tapak Suci, yaitu pemberian hukuman dan pembinaan mental. Kedua strategi tersebut menggunakan paksaan yang banyak dilarang dalam penanaman karakter, sebaliknya justru dibutuhkan dalam menanamkan karakter jujur dan disiplin bagi para siswa SMK Muhammadiyah 2 Blora. Pemberian hukuman dan pembinaan mental memberikan efek jera dan membuat mereka menyadari kesalahannya. Pemberian hukuman dan pembinaan mental yang erat dengan cara paksaan, justru menjadi cara yang efektif bagi Tapak Suci dalam menanamkan karakter jujur dan disiplin bagi para siswa SMK Muhammadiyah 2 Blora.

Akhirnya penanaman karakter jujur dan disiplin yang diimplementasikan melalui pembinaan-pembinaan dalam ekstrakurikuler wajib Tapak Suci di SMK Muhammadiyah 2 Blora tidak hanya dipraktikkan oleh para siswa dalam kegiatan ekstrakurikuler wajib Tapak Suci. Akan tetapi, nilai karakter jujur dan disiplin juga berhasil diterapkan atau dipraktikkan dalam lingkup kehidupan yang lainnya. Baik itu di dalam lingkup sekolah maupun di lingkup tempat tinggal para siswa SMK Muhammadiyah 2 Blora.

\section{Ucapan Terima Kasih}

Penulis mengucapkan terima kasih yang sebesar-besarnya kepada warga SMK Muhammaiyah 2 Blora yang telah membantu terselesaikannya penelitian ini dan semua pihak yang tidak dapat disebutkan satu per satu. Selain itu penulis juga mengucapkan terima kasih kepada redaksi Jurnal Dimensia Universitas Negeri Yogyakarta yang telah menerbitkan artikel ini sehingga dapat menjadi kajian dan referensi selanjutnya bagi penelitian yang relevan.

\section{Daftar Pustaka}

Direktorat Dikmenjur. 2003 . Petunjuk Teknis Pelaksanaan Program Imbal Swadaya SMK Kecil. Jakarta: Departemen Pendidikan Nasional.

Patrisius Istiarto Djiwandono. (2015). Meneliti Itu Tidak Sulit : Metodologi Penelitian Sosial dan Pendidikan Bahasa. Yogyakarta: Deepublish.

Yanuar H. 2015. "Menteri Anies: Pencak Silat Bagian Pembentukan Karakter Anak. Jakarta". https://www.liputan6.com/news/r ead/2176029/menteri-aniespencak-silat-bagianpembentukan-karakter-anak. Diakse pada 19 Januari 2019

La Hadisi, "Pendidikan Karakter Pada Anak Usia Dini", Jurnal Al-Ta'dib, Vol. 8, No.2, 2015. 64

Hamdi, dkk. 2014. Metodwe Penelitian Kuantitatif Aplikasi dalam 
Pendidikan. Yogyakarta:

Deepublish.

Awan Hariono. 2008. Pencak Silat Sebagai Sarana Pembentukan Karakter. Seminar Olahraga Nasional Ke II . Yogyakarta: Universitas Negeri Yogyakarta.

Sri Hartini, "Pendidikan Karakter Disiplin Siswa di Era Modern Sinergi Orang Tua dan Guru di MTS Negeri Kabupaten Klaten", $A L$ ASASIYYA : Journal Basic Of Education, 2017

Kemendiknas. 2011. Panduan Pelaksanaan Pendidikan Karakter. Jakarta: Badan Penelitian dan Pengembangan Pusat Kurikulum dan Perbukuan.

Erwin Setyo Kriswanto. 2015. Pencak Silat (Sejarah dan Perkembangan Pencak Silat, Teknik-Teknik dalam Pencak Silat, Pengetahuan Dasar Pertandingan Pencak Silat). Yogyakarta:

PUSTAKABARUPRESS.

Meilinda Dwi Lestari. 2018. Penanaman Karakter Religius, Disiplin dan Tanggungjawab Peserta Didik Melalui Ekstrakurikuler Tapak Suci Putera Muhammadiyah di SMA Muhammadiyah 1 Ponorogo. Ponorogo: Institut Agama Islam Negeri Ponorogo.

Morissan. 2017. Metode Penelitian Survey. Jakarta: KENCANA.

Mulyana. 2013. Pendidikan Pencak Silat: Membangun Jati Diri dan Karakter. Bandung: PT Remaja Rosdakarya.

Empi Muslion.2018. Kontemplasi Demokrai, Politik dan Pemerintahan Pasca Reformasi. Yogyakarta: Deepublish.

Mohammad Nuh. 2013. Pedoman Kegiatan Ekstrakurikuler. Jakarta: Kementerian Pendidikan dan Kebudayaan Republik Indonesia.

Murdiyastomo, H. A. (2017). Serat Wedatama and character education. Journal of Social Studies (JSS), 13(1). 63-69. https://doi.org/10.21831/jss.v13i 1.16974

Poerwandari. 2001. Pendekatan Kualitatif untuk Penelitian Perilaku Manusia. Jakarta: Lembaga Pengembangan Sarana Pengukuran dan Pendidikan Psikologi (LPSP3) Fakultas Psikologi Universitas Indonesia.

Noviani Achmad Putri. 2011. Penanaman Nilai-Nilai Pendidikan Karakter Melalui Mata Pelajaran Sosiologi. Komunitas.

Ashifa Quamila. 2018. Pengaruh Latihan J-Bands Exercise Terhadap Peningkatan Daya Ledak Otot Lengan pada Pukulan Atlet Pencak Silat di Universitas Muhammadiyah Malang. Malang: Universitas Muhammadiyah Malang.

Rahmawati,dkk. 2015. Perilaku Menyontek Ditinjau dari Orientasi Tujuan Belajar Siswa SMA/MA di Surakarta. Semiar Nasional Pendidikan Ekonomi \& Bisnis (p. 02). Surakarta: Universitas Negeri Sebelas Maret.

Sukarni, dkk. 2016. Tapak Suci dan Karakter Siswa. Equilibrium.

Nana Syaodih Sukmadinata. 2005. Metode Penelitian Pendidikan. Bandung: Remaja Rosda Karya.

Sumadi, dkk, "Pengaruh Disiplin Sekolah terhadap Prestasi Belajar Siswa Pelajaran Ekonomi di MAN 2 Filial", Jurnal Pendidikan dan Pembelajaran Vol. 4, No 9, 2015.

Singh, B. (2019). Character education in the 21st century. Journal of Social Studies (JSS), 15(1). 112.https://doi.org/10.21831/jss.v1 $5 i 1.25226$.

Lulu Putri Utami. 2016. PLS Sebagai Solusi Alternatif Kenakalan dan Degradasi Remaja. Serang: Universitas Sultan Ageng Tirtayasa.

Agus Wibowo. 2013. Manajemen Pendidikan Karakter di Sekolah. Yogyakarta: Pustaka Pelajar.

Wulandari, dkk, "Pengaruh Reward and Punishment terhadap Motivasi 
Belajar Siswa dalam

Pembelajaran Passing Bawah

Bola Voli", Jurnal Pendidikan

Olahraga dan Kesehatan, Vol 2, 2014, 600.

Zulfah, Z., \& Shofa, R. A. (2019). Information checking as a form of character management in education. Journal of Social Studies (JSS), 15(1). 63-76. HYPERLINK

"https://doi.org/10.21831/jss.v15i1. 32809" 